\title{
NAXE wt Allele
}

National Cancer Institute

\section{Source}

National Cancer Institute. NAXE wt Allele. NCI Thesaurus. Code C106642.

Human NAXE wild-type allele is located in the vicinity of $1 \mathrm{q} 22$ and is approximately $3 \mathrm{~kb}$ in length. This allele, which encodes $\mathrm{NAD}(\mathrm{P}) \mathrm{H}$-hydrate epimerase protein, is involved in both NAD metabolism and apolipoprotein A-I binding. 